\title{
RETRACTION: Enhanced insulin sensitivity, energy expenditure and thermogenesis in adipose-specific Pten suppression in mice
}

N Komazawa, M Matsuda, G Kondoh, W Mizunoya, M Iwaki, T Takagi, Y Sumikawa, K Inoue, A Suzuki, T W Mak, T Nakano, T Fushiki, J Takeda \& I Shimomura

Nat. Med. 10, 1208-1215 (2004)

In the process of following up the findings reported in this study, we were unable to reproduce the original results. By carefully examining the first author's notebook, we found that some of the primary data were erroneously or artificially presented in the paper. Under these circumstances, all authors unanimously wish to retract this paper as soon as possible. We deeply apologize to the readers for any inconvenience caused by this retraction.

\section{RETRACTION: Turning up the heat in the fat cell}

D Accili \& L Valenti

Nat. Med. 10, 1168-1169 (2004)

In view of the fact that the authors of "Enhanced insulin sensitivity, energy expenditure and thermogenesis in adipose-specific Pten suppression in mice" no longer stand by their results, we wish to retract the views reported in our News and Views article, which dealt with the above study. 